\title{
Consumers' Views of the Strategies for Promoting Peace and Sustainable Development in the Niger Delta Region
}

\author{
T. A. Akanji \\ Department of Adult Education \\ University Of Ibadan, Ibadan, Nigeria \\ Mabel Oyitso \\ Department of Adult and Non-Formal Education \\ University of Benin, Benin City, Nigeria \\ E-mail: oyitsom@yahoo.com
}

Received: February 10, 2012

Accepted: April 26, $2012 \quad$ Published: June 1, 2012

doi:10.5539/res.v4n2p168

URL: http://dx.doi.org/10.5539/res.v4n2p168

\begin{abstract}
This study focused on the consumers' views of the strategies for promoting peace and sustainable development in the Niger Delta region. Stratified proportional random sampling technique was used to select one thousand four hundred and seventy (1470) respondents from nine communities in Delta, Bayelsa and Rivers State constituted the sample used for the study. A questionnaire was developed by the researchers and used for the collection of data. The analysis was done using frequency count, simple percentages and mean scores for ranking. The results revealed that the respondents were of the views that peace and sustainable development can be achieved in the Niger Delta Region through the following ways: Community people should be involved in the planning and execution of projects, there should be effective communication among stakeholders, employment creation, youth empowerment through acquisition of skills and massive infrastructural development. Based on the findings, it was recommended among other things that part of the $13 \%$ derivation fund should be used solely to develop the region and also that youths be empowered through skill acquisition to curb youth restiveness in the region. To ensure sustainable development, community people should be involved in initiating, planning and execution of community development projects.
\end{abstract}

Keywords: Strategies, Peace, Sustainable development, Promoting and Niger Delta

\section{Introduction}

\subsection{Historical background}

The Niger Delta is a veritable geographical curiosity which spans over 70 square kilometers and four ecological zones (Oyerinde 1998). The zones are coastal ridges, barrier fresh-water swamp forest and low land rain forest (Dadiowei, 2003). It is also rated as one of the world largest expanse of wetland with the ninth vastest drainage area in the world and the third largest mangrove forest. The Niger Delta area is an ethnographic melting point with over 25 distinct lingual groups areas. In terms of resource endowment, it is clearly the richest region in Nigeria, accounting for about $70 \%$ of the country's hydrocarbon resources especially crude oil and natural gas. Though the region, provides the oil wealth of the nation, it is characterized by environmental degradation and pollution, destruction of local economic resources, poor infrastructure development and outright neglect. The emerging dimension to the issue is that of multiple ethnic groups, communal and youth associations who now confront the multinational oil companies and the Federal government over inadequate compensation and prolonged neglect, coupled with underdevelopment of the region. Associated with this, is the increasing emergence of militancy and violence between oil communities on the one hand and the oil companies on the other. Evidence of these includes the seizure of or threats to seize oil installations, machineries and abduction of staff. 
In 2004, seven expatriates of Brendero Shaw (an oil servicing firm) were kidnapped and killed along the Benin River in Delta state by militant youths in Ogheye Creeks in Warri local government area of the state (Vanguard, 2004). Four Ugborodo indigenes were also killed in 2005, while protesting the non - implementation of memorandum of agreement between their community and Cheveron - Texaco. Before now, there have been significant killings by government troops in Ogoni land, Odi and Ikwere (Chokor, 2005). On the $20^{\text {th }}$ of July, 2006 women and youths of various communities in Jesse clan in Ethiope West local government area of Delta state protested over the alleged spills resulting from the pipelines of the Nigeria National Petroleum Corporation which destroyed their means of livelihood especially farming and fishing (Vanguard 2006:13).

The multinational oil cooperations operating within the Niger Delta region have dominated the region for several decades with their activities of exploration and exploitation which have left the region underdeveloped while the oil exploration have left behind a trail of social -human devastation in terms of ecological destruction, environmental pollution, social, economic and cultural dislocation. According to Kareem, (2000) the attendant poverty, unemployment, and deplorable living conditions have generated anger, frustration, hostility and violence which are seen as appropriate responses to the neglect of the companies' social responsibility to its host communities. As a result, communities in the Niger Delta region strongly feel that they have not had a reasonable share of the oil revenue from the Nigerian Government following over 50 years of oil production from their land, considering their poor standard of living compared to people in other areas of Nigeria. Many still lack basic amenities such as electricity, portable drinking water, good and accessible roads, sewage treatment facilities and health clinics and have limited opportunities for employment. The debate over appropriate strategy for managing problems in oil producing areas of Nigeria is as fierce today as it was over 50 years ago. This has been the aftermath of the Willinks commission report of 1958, (Akaruese 1998: 149). The commission states that:

"the needs of those who live in the Creeks and swamps of the Niger Delta are very different from those of the interior, the country in which they live is divided by Creeks and inlets of the sea and of the Niger into small islands, which nowhere rise far above the highest tides and floods, transport by water and the construction of roads or railways will be prohibitively expensive. There is a country which has been neglected and which is unlikely ever to be highly developed (Willink's Commission Report 1958. 8)

Following the Willink's minority's commission 1958 report, the Niger Delta Board (NDDB) was established in 1959 to advice the government of the Federation and the Midwestern and Eastern Nigeria with regards to physical development of the Niger Delta which failed because of lack of sustained mission and chronic underfunding. As a result of these, successive governments have experimented with various strategies to ameliorate the developmental gap in the oil producing communities. Some of these strategies include:

- The establishment of an interventionist agency called the Presidential task force and popularly known as 1.5 percent committee replace the NDDB in 1980.

- The formation of the oil mineral producing area of development commission (OMPADEC) which was set up by decree No 23 of 1992 to rehabilitate, carry out infrastructural and manpower development, offer environmental protection from pollution.

- The setting aside of $13 \%$ of net contribution of proceed of oil as the Derivation fund to develop the oil producing areas.

- The Niger Delta development commission (NDDC) was established in 1999 by former President Olusegun Obasanjo to deal urgently with the developmental needs of the Niger Delta and bring sustainable prosperity and peace to the area.

The expectation is that the setting up of the NDDC would bring development to the region thereby addressing the basic needs of identity, freedom, well-being and survival and thereby significantly contributes towards the realization of sustainable peace in the Niger Delta area. However, the impact of the commission has not been felt in the region especially in the rural areas and this has further worsened the crises situation in the region.

Furthermore, the Niger Delta peace forum was initiated by late Umar Musa Yar dua in 2007 comprising the governors of oil producing communities, oil companies operating in the area and all other stake-holders to chart a new course to address the lingering crises in the area in order to bring peace and development to the region. In the same vein, the Ministry of Niger Delta was created to further address the problems of the region. An amnesty programme was also created by the Federal government in June 2009 whereby militants were required to surrender their weapons and in return received presidential pardon, education, training and access to 
rehabilitation programme. All these were aimed at bringing peace to the Niger Delta region. The problem of the Niger Delta region still persist till date in spite of the various intervention agencies and programmes put in place by government to address the problem. Against this backdrop, there is need to put in place other strategies that will bring peace and sustainable development to the region.

\subsection{Statement of the problem}

The Niger Delta is reputed to have a high concentration of crude oil deposit in Nigeria. It is estimated that crude oil exploration from the area contributes roughly $90 \%$ of the country's foreign exchange; however, this apparent good fortune has become a major source of distress to the region. It is the belief that the money generated is not ploughed back to develop the oil producing region. This unfortunate situation in turn appears to occasion the spate of agitations, crises, restiveness and intra - communal conflicts in the region (as in the case of Ijaw-Itsekiri, Ijaw-Ilaja) and degradation of the physical and biological environment of the area has heightened tension and poverty.

In spite of the various economic measures like the formation of OMPADEC, NDDC and the establishment of the Ministry of Niger Delta by the present administration to address the needs of the people and formulate and coordinate policies for the development of the Niger Delta region, intra and inter communal conflicts, youth restiveness, hostage taking of oil workers and pipe line vandalization still pervade the region. It is assumed that the existing structures and approaches used by government and the execution of the community development projects in oil producing communities would foster peace in the region but crisis still pervade the region. What then can be done to bring the desired peace and development to the region? Therefore, there is the need for more appropriate strategies to be put in place to promote peace and sustainable development in the region. The answer to the above question and the possible solution to the problem can only be found from the affected (consumers) victims, hence this study.

\subsection{Purpose of the study}

The main purpose of the study is to:

(i) Find out what strategies that can be used to promote peace and sustainable development in the Niger Delta Region.

(ii) Determine the rank order of the strategies to promote peace and sustainable development in the region.

\subsection{Research questions}

(i) What are the strategies that can be used to promote peace and sustainable development in the Niger Delta Region?

(ii) What is the rank order of the strategies to promote peace and sustainable development in the region?

\section{Literature Review}

Development cannot take place in the Niger Delta region in the midst of violent protests and conflicts, hence there is need to develop strategies to bring peace and sustainable development to the region. According to Omeweh (2005) development should be experiential and people centred. He noted that the problem is not so much about the absence of development but it is about the nature of the development being promoted. Development should be derived from the past social, cultural and economic experiences of the people and should not be imposed on them or determined for them by external forces. Also supporting this view Roberts (2005) advocated that governments and NGOs promoting sustainable development in the Niger Delta must be people centred and participatory. Hence Roberts (2005) reasoned that any serious development intervention that aims at sustainability must be holistic and participatory, placing the people of the Niger Delta region at the core of development.

Furthermore, another way to the development of the Niger Delta is through capacity building (Ibeanu 2005). He is of the opinion that one important challenge facing sustainable development in the Niger Delta is to rekindle the latent energy of the people to solve their own problem by creatively seizing the opportunity and transforming the biophysical and social environments in which they live. This calls for a reawakening of entrepreneurial culture and innovative use of indigenous knowledge to manage natural resources and creative sustainable livelihood. Supporting this view, Roberts (2005) said that for participation in sustainable livelihood to be successful, local clients must be equipped with relevant skills that will enable them to work in new ways in their old vocations or in new vocations.

On his part, Onduku (2003) is of the view that sustainable peace can be achieved in the region through economic, environmental and social development and sustainable peace in the region should embrace options for positive 
peace which revolves around addressing issues of poverty, environmental degradation, political, economic and social justice, low level of literacy and unemployment. This forms the core of human security in the region. Fawudu (2006) proposed the following for the resolution of the crisis and sustainable development of the region to include:

- Government should promote peace as a foundation for development because there cannot be any meaningful development without peace.

- Improve and diversify the economy.

- Promote social inclusion and improve access to social services, a major concern is the nation's longstanding exclusion of some people from the mainstream of Nigeria' social economic and political activities.

- Promote environmental sustainability to preserve the means of peoples' sustainable livelihood and build sustainable partnerships for the advancement of human development.

For enduring peace to reign in the Niger Delta, it must be aided by social justice expressed in meeting the legitimate demands and expectations of the people of the Niger Delta. The Nigerian state should not expect that dialogue alone is a panacea; it must be backed by massive investment in the Niger Delta, investment in infrastructure and environmental protection. A constitutional provision must be made for revenue allocation to the region. It must be noted that peace is not an event but a process (Idoko, 2002).

\section{Methodology}

The descriptive survey research design was adopted for this study. The population for this study consists of the inhabitants of the nine selected communities of the Niger Delta region. Stratified proportional random sampling technique was used to select 1470 respondents from three (3) local government areas in each of Delta, Bayelsa, and Rivers state. The instrument used for the study was titled Community-based institutions and Peace-building questionnaire. This was completed with six (6) sessions of Focus Group Discussions (FGD). The content validity of the instrument was determined by experts in educational programme evaluation in the Faculty of Education, University of Benin.

The reliability was determined through a test-retest method. A small sample size of 30 respondents was used in the test. They were tested with the research instrument, that is the questionnaire and their responses were rated and scored. After a period of two weeks, the sample was re-tested. Subsequently, the scores of both tests were used as a means of computing the reliability coefficient and 0.75 co-efficient was obtained. The data collected was analyzed using the inferential statistics of frequency counts, mean scores and simple percentages.

\section{Results}

The findings of the study are presented below.

\subsection{What strategies can be used to promote peace and sustainable development in the Niger Delta region?}

Table 1 shows the suggested strategies through which peace and sustainable development can be achieved in the Niger Delta Region. Majority of the respondents $(87 \%)$ indicated that effective communication among stakeholders will bring peace and sustainable development to the region, $(87.6 \%)$ of them said that involvement of community people in planning and execution of projects, $(85.8 \%)$ believe that provision of employment, $(84.1 \%)$ believe it is through youth empowerment and skill acquisition for self reliance, $(85.5 \%)$ agreed that it is through infrastructural development of the region, $(66.8 \%)$ said that making local people control their resources will bring peace and sustainable development to the region.

\subsection{Rank order of the suggested strategies for promoting peace and sustainable development in the Niger Delta region}

Result presented in Table II shows that involvement of community people in the planning and execution of projects ranked $1^{\text {st }}$. This is followed by effective communication among stakeholders ranked $2^{\text {nd }}$, followed by provision of employment, empowering youth through skill acquisition and making local people to control their resources which ranked $4^{\text {th }}, 5^{\text {th }}$ and $6^{\text {th }}$ respectively. From the responses, it is obvious that involvement of community people in planning and execution of projects, effective communication among stakeholders and infrastructural development are the most effective strategies that can bring peace and sustainable development to the region. 


\section{Discussion of Findings}

The findings of the study revealed that in the opinion of the people, the strategies through which peace and sustainable development can be achieved in the Niger Delta region is through effective communication among stakeholders, involvement of community people in the planning and execution of projects, provision of employment, youth empowerment through skill acquisition, infrastructural development and making local people to control their resources. The view of Ibeanu (2008) confirms the findings that effective communication among stake-holders will bring peace and sustainable development to the region. Confidence can be built among stake-holders in the Niger Delta region through strengthening channels of communication and exchange of views. The findings, in terms of involvement of community in planning and execution of projects is in keeping with Roberts (2005) views that development must be people centre and participatory. There is need for community based participatory development strategies which secure ownership for local community and ensure the sustainability of development projects. The findings are in line with Ogboi's (2003) recommendation that programmes and projects aimed at communities in improving the quality of life in the region should reflects the needs and prioritized by the people themselves. He suggested that there should be community involvement through active participation in initiating, planning, executing and decision taking as regards programmes and projects to be embarked upon. This will ensure full participation of the local people. Ogboi's study has shown that the people of local communities are in better position to determine their needs more than government, professional or any other persons. The findings on provision of employment and empowerment of youths through skill acquisition as a means to ensure peace and sustainable development in the region is in keeping with Roberts (2005) who suggested that local people must be equipped with relevant skills that will enable them to function in new ways, in their old vocation or in new vocation. This, he said underlines the importance of human resource and training and skill acquisition programmes. Based on Iheriohanma's findings in his study, recommended that capacity building and utilization is the only approach through which the productive capacity and potentials of the oil producing rural dwellers can be improved and utilized.

In addition, Ikporukpo (1998) believes that popular participation, empowerment of the ordinary citizens especially oil producing communities and the rigorous pursuit of infrastructural transformation of oil producing rural communities will foster harmony between the host communities and oil exploiting companies elicit participation and attitude of people towards oil companies operating in the area. This also suggests that the process structure gap suggested by Lederach (1999) entails the process of putting structures that will bring peace and sustainable development. Moreover, Erue (2009) believes that the Niger Delta region can only be peaceful through the creation of massive job opportunities in the region within the development of a functional agro-industrial complex. Similarly, Iyayi (2005) agreed that the alternative path to peace and sustainable development in the region include the total economic and social rehabilitation of the region and the empowerment of the people.

On the strategies to be adopted for developing the Niger Delta region for sustainable peace and development, discussants at Elegbele FGD session are of the opinion that:

Infrastructural development of the region, construction of roads, scholarship scheme should be initiated, loans to be given to help them set up their own business, contract should be given to indigenes, there should be youth empowerment through skill acquisition and after acquiring the skill, money should be given to the youth to enable them set up their own business, recreational facilities should be created for the relaxation of community members

\section{Men/Youth FGD/Elegbele/Ogbia LGA/Bayelsa State/13/05/09.}

In the same vein, discussants from Obagi focus FGD session suggested that:

There should be infrastructural development in the region, industries should be established so as to generate employment for the unemployed, skill acquisition centres should be created in the community where people will be trained, and also constant seminars should be held to equip community members with skills on how to start up their own business.

\section{Men/Youth FDG/Obagi/Ogba/Egbema LGA/Rivers/State/16/05/09.}

Also, the discussants at Bodo in Gokana FGD session noted that:

An idle mind is the devil's workshop; hence, participants suggested employment opportunity should be created to employ the jobless youth in the community. People should be empowered through skill acquisition, social amenities like electricity and water should be provided, hospital to be equipped and staffed with qualified personnel to run the place. 


\section{Men/Youth FGD/Bodo/Gogana LGA/Rivers State/17/05/09.}

Furthermore, discussants at Biseni submitted that:

Industry should be cited in the community to create employment for people, there should be infrastructural development like construction of roads, provision of pipe-borne water and building of a general hospital in the locality and skill acquisition centres should be established where youth can be empowered.

\section{Men/Youth FGD/Biseni/Yenogoa LGA/Bayelsa State/14/05/09.}

\section{Conclusion/Recommendation.}

The study focused on consumers' views on the strategies for promoting peace and sustainable development in the Niger Delta region. The data derived from the study revealed that according to the clients, peace and sustainable development can be achieved through the following strategies: Effective communication among stakeholders, involvement of community people in planning and execution of projects, provision of employment, youth empowerment through skill acquisition and massive infrastructural development of the region.

Based on the findings, the following recommendations are hereby made:

- The people should be involved in initiating, planning and the execution of project in the community. This will ensure the utilization and maintenance of such projects.

- There should be massive infrastructural development of the region since the region provides the oil wealth of the nation. To this end part of the derivation fund should be used for the development of the region.

- The youth from the region should be empowered through skill acquisition to reduce youth restiveness.

- There should be periodic meeting among stake-holders to interact and share ideas on how the region can attain peace, progress and sustainable development.

\section{References}

Amadi \& Bamidele (Ed). Towards an integrated of the Niger Delta, Centre for democracy and delopment (pp. $1-75)$.

Chokor, B. A. (2005). Humanistic approaches to environmental assessment with case study from Niger Delta, perspective on development. Centre for Population and Environmental Development (pp. 312-377).

Delta, K., Fayemi, S. A., \& Bamidele (Eds). Towards an integrated development of the Niger Delta center for demoncracy and development (pp. 1-75).

Erue, S. (2009). Make Amnesty Go with Development of Niger Delta, Vanguard, Monday August $3^{\text {rd }}$.

Fawundu, A. (2006). Niger Delta human development report, United Nations development report (UNDP), Garki, Abuja.

Ibeanu, O. (2008). Affluence and affliction: The Niger Delta as a critique of political science in Nigeria, Inaugural lecture series. University of Nigeria.

Idoko, N. (2008). Niger Delta challenge of violence. The Nation, Tuesday July $8^{\text {th }}, 20$.

Kareem, E. (2000). Multi-national corporation and their impact on the development of host communities. Unpublished M.Sc. Thesis. Department of political Science and Public administration University of Benin. Tiv85.

Lederach, J. P. (1999). Just peace in European centre for conflict prevention. People building peace, 35; inspiring stories around the world, 29.

Ogboi, K. C. (2003). An assessment of community development needs in the Niger Delta: a case study of Isoko land. Unpublished Ph.D Thesis, Department of Goegraphy and Regional planning, University of Benin.

Omoweh, D. A. (2005). Petroleum production, environment degradation and conflict in the Niger .

Onduku, A. (2003). Confronting the human security dilemma towards building sustainable peace in the Niger Delta. [Online] Available: www. nigerdeltacongress . com / articles confronting - the- human-security d. htm

Roberts, F. O. N. (2005). In Fayemi, K. S., Environment and Livelihoods in the Niger Delta.

Willinks Commission. (1958). report, London, Colonial office. 
Table1. Consumers' opinion of the strategies for promoting peace and sustainable development in the Niger Delta Region

\begin{tabular}{|c|c|c|c|c|c|c|}
\hline $\mathrm{S} / \mathrm{N}$ & Strategies & A & SA & SD & SD & Total \\
\hline 1 & $\begin{array}{l}\text { Effective communication among } \\
\text { stakeholders will bring peace and } \\
\text { sustainable development to the region }\end{array}$ & $\begin{array}{c}686 \\
(46.7 \%)\end{array}$ & $\begin{array}{c}593 \\
(40.3 \%)\end{array}$ & $\begin{array}{c}99 \\
(67 \%)\end{array}$ & $\begin{array}{c}92 \\
(6.3 \%)\end{array}$ & $\begin{array}{c}1470 \\
(100 \%)\end{array}$ \\
\hline 2 & $\begin{array}{l}\text { Involvement of community people in } \\
\text { planning and execution of project will } \\
\text { ensure peace in and sustainable } \\
\text { development in the region }\end{array}$ & $\begin{array}{c}838 \\
(57 \%)\end{array}$ & $\begin{array}{c}449 \\
(30.5)\end{array}$ & $\begin{array}{c}78 \\
(5.3 \%)\end{array}$ & $\begin{array}{c}105 \\
(7.1 \%)\end{array}$ & $\begin{array}{c}1470 \\
(100 \%)\end{array}$ \\
\hline 3 & $\begin{array}{l}\text { Provision of employment would ensure } \\
\text { peace and sustainable development in } \\
\text { the region }\end{array}$ & $\begin{array}{c}613 \\
(41.7 \%)\end{array}$ & $\begin{array}{c}648 \\
(44.1 \%)\end{array}$ & $\begin{array}{c}82 \\
(5.6 \%)\end{array}$ & $\begin{array}{c}127 \\
(18.6 \%)\end{array}$ & $\begin{array}{c}1470 \\
(100 \%)\end{array}$ \\
\hline 4 & $\begin{array}{l}\text { Empowering the youth through skill } \\
\text { acquisition for self reliance }\end{array}$ & $\begin{array}{c}628 \\
(42.7 \%)\end{array}$ & $\begin{array}{c}609 \\
(41.1 \%)\end{array}$ & $\begin{array}{c}90 \\
(13.5 \%)\end{array}$ & $\begin{array}{c}143 \\
(17.1 \%)\end{array}$ & $\begin{array}{c}1470 \\
(100 \%)\end{array}$ \\
\hline 5 & Infrastructural development & $\begin{array}{c}666 \\
(45.3 \%)\end{array}$ & $\begin{array}{c}591 \\
(41.4 \%)\end{array}$ & $\begin{array}{c}87 \\
(5.9 \%)\end{array}$ & $\begin{array}{c}126 \\
(8.6 \%)\end{array}$ & $\begin{array}{c}1470 \\
(100 \%)\end{array}$ \\
\hline 6 & $\begin{array}{l}\text { Building of cottage industry to provide } \\
\text { employment for people in the locality }\end{array}$ & $\begin{array}{c}876 \\
(59.6 \%)\end{array}$ & $\begin{array}{c}417 \\
(28.4 \%)\end{array}$ & $\begin{array}{c}56 \\
(3.8 \%)\end{array}$ & $\begin{array}{c}121 \\
(8.2 \%)\end{array}$ & $\begin{array}{c}147 \\
100 \%\end{array}$ \\
\hline 7 & $\begin{array}{l}\text { Making local people to control their } \\
\text { resources }\end{array}$ & $\begin{array}{c}571 \\
(38.8 \%)\end{array}$ & $\begin{array}{c}412 \\
(28 \%)\end{array}$ & $\begin{array}{c}258 \\
(81 \%)\end{array}$ & $\begin{array}{c}229 \\
(1 \%)\end{array}$ & $\begin{array}{c}1470 \\
(100 \%)\end{array}$ \\
\hline
\end{tabular}

Table 2. Rank order of the suggested strategies for promoting peace and sustainable development in the Niger Delta region

\begin{tabular}{cccc}
\hline S/N & Strategies & $\begin{array}{c}\text { Mean } \\
\text { Response }\end{array}$ & $\begin{array}{c}\text { Rank } \\
\text { Order }\end{array}$ \\
\hline 1 & Involvement of community people in the planning and execution of \\
projects & 3.37 & $1^{\text {st }}$ \\
2 & Effective communication among stakeholders & 3.27 & $2^{\text {nd }}$ \\
3 & Infrastructural development to the region & 3.22 & $3^{\text {rd }}$ \\
4 & Provision of employment & 3.19 & $4^{\text {th }}$ \\
5 & Empowering the youth through skill acquisition & 3.17 & $5^{\text {th }}$ \\
6 & Making the local people to control their resources & 2.89 & $6^{\text {th }}$ \\
\hline
\end{tabular}

